\title{
ENVIRONMENTAL TECHNOLOGICAL INNOVATION AND ITS CONTRIBUTION TO SUSTAINABLE DEVELOPMENT
}

\author{
Muhammad Fakhrul Yusuf ${ }^{1,2}$, Hasbullah Ashari ${ }^{2}$, Mohd Rizal Razalli ${ }^{2 *}$ \\ ${ }^{1}$ Faculty of Industrial Management, Universiti Malaysia Pahang, Lebuhraya Tun Razak, \\ 26300 Gambang Kuantan, Pahang Darul Makmur, Malaysia \\ ${ }^{2}$ School of Technology Management \& Logistic, Universiti Utara Malaysia, \\ 06010 UUM Sintok, Kedah Darul Aman, Malaysia
}

(Received: July 2018 / Revised: September 2018 / Accepted: December 2018)

\begin{abstract}
Globally, global warming, resource depletion, and increased solid waste volumes have become major concerns for international governments. This paper aims to address Malaysia's competitiveness in the context of global environmental change by analyzing firms that have incorporated environmental technological innovation (ET innovation) in their operations. This paper illustrates the connections between ET innovation and sustainable development and discusses the implementation of ET innovation at a firm level. The firms selected for this study focused on the whole spectrum of ET innovation when implementing their environmental technologies. These firms also targeted international markets with their eco-products and green technologies. However, we established that they need to become more market-oriented during the development of their products and technologies so that they address market needs. The involvement of firms in ET innovation requires significant investment in R\&D and the proper management of resources to be successful.
\end{abstract}

Keywords: Concept relationship diagram; Environmental innovation; Malaysia; Review; Sustainable development

\section{INTRODUCTION}

The concept of sustainable development was first proposed as early as the 1980s. It was initially defined as taking into account the effects of social, economic, and ecological factors, in addition to the living and non-living resource base, with consideration of current and future population needs and the long- and short-term advantages and disadvantages of alternative development activity (WCED, 1987; Dalal-Clayton \& Bass, 2000). Sustainable development requires that nations take the necessary precautions and implement preventative activities in the areas of technology, science, and politics to ensure global sustainability. For example, each development program should consider the regenerative and absorptive capacities of materials and energy and maintain its output growth below the stipulated threshold stated by the UN and agreed by the government of the country (Gladwin et al., 1995).

New technologies can offer new methods to handle identified international preventative and precautionary obligations while saving resources and reducing consumption. They are also key to economic growth and competitive advantage, which makes them very important in the fight against poverty. At the same time, they can mitigate against practices that threaten the 
environment through the unsustainable use of resources (WCED, 1987; Porter, 1990). Not with standing, new technologies can also produce new ways to pollute and alter the earth's natural evolutionary progress (WCED, 1987). It is therefore important for technological and scientific researchers to be responsible and take precautions against these possibilities (Gladwin et al., 1995). In addition, it is difficult for industry to control a technology by simply adopting it. To maintain control of technology, firms need to implement environmental technological innovation (ET innovation) as a sustainable development tool (Elkington, 1994; Kemp, 2010).

Accordingly, it is important to understand the contribution and relationship of ET innovation with eco-innovation, innovation, and ultimately, sustainable development. In the case of the Malaysian manufacturing industry in particular, it is imperative to demonstrate that the implementation of ET innovation is genuine and the issues being addressed are tangible. This study briefly describes a few examples of ET innovation in Malaysia using case studies of selected firms. The explanations in the subsections are based on the concept relationship diagram in Figure 1 (BSI/ISO, 2015). We then examine current ET innovation implementation in the manufacturing industry in Malaysia. Section 2 explains the methodology used while the implications are discussed in Section 3, with our conclusions in Section 4.

\subsection{Sustainable Development}

Sustainability is one of the most debated terms in the modern era (Seghezzo, 2009). The term was first used in the environmental sense by Hans Carl von Carlowitz, a German forester, in his book Sylvicultura Oeconomica (1712) in which he described how forests can be managed on a long-term basis. In the late 1960s and 1970s, an environmental movement started to emerge. Environmentalists were keen to adopt the concept of "greening the economy" so that environmental issues could be related to economic development (Turcu, 2013).

In 1969, the Secretary-General of the United Nations, the Honorary Mr. U Thant, stressed the long-term problems of modern man, which at that time included the arms race, environmental deterioration, the population explosion, and economic stagnation. There were several debates about the limited carrying capacity of the planet, which would hinder economic growth from continuing indefinitely. This was recorded in the controversial report Limits to Growth, which was commissioned by the Club of Rome. At the beginning of the 1970s, technologists also started to shift their emphasis and, alongside the technical and economic focus of their existing approach, added social and ecological implications (Meadows et al., 1972; Pansera, 2012).

The term "sustainable development" was first used in Stockholm at the United Nations Conference on the Human Environment in 1972. However, the first official definition was only introduced by a three-partite union in the World Conservation Strategy (WCS) report in 1980: "For development to be sustainable, it must take account of social and ecological factors, as well as economic ones; of the living and non-living resource base; and of the long-term as well as the short-term advantages and disadvantages of alternative action" (Kruja, 2013). In the WCS report, the union, which consisted of the former International Union for Conservation of Nature (now the World Conservation Union), the United Nations Environment Programme, and the World Wildlife Fund, advocated for balance in development and conservation in attempt to secure the earth for people to live in comfort and happiness (Dalal-Clayton \& Bass, 2000; Pansera, 2012). This sparked an effort to develop the Brundtland Report in 1987. The Brundtland Commission provided a definition for sustainable development that continues to be used today. It stated: "Humanity has the ability to make development sustainable to ensure that it meets the needs of the present without compromising the ability of future generations to meet their own needs" (WCED, 1987).

The 1987 Brundtland Commission Report on sustainable development focused on the three broad areas of environmental, economic, and social activities (Figure 1[a]). Each area 
contributes to and disrupts the others in a special relationship that was initially advocated by Rachel Carson in her book Silent Spring, which was published in 1962 (WCED, 1987; Giddings et al., 2002).

For sustainable development to be achieved and the well-being of present and future generations to be improved, technological innovation and social organization needs to be enhanced. Social organization can be improved and managed through innovation at institutional, national, and international levels (WCED, 1987). Innovation in organizations and technology are parts of the concept of eco-innovation. Nevertheless, it must also be emphasized that environmental thinking must be embedded in all aspects of social, political, and economic activities for the concept of sustainable development to succeed. Therefore, it can be concluded that eco-innovation has a direct relationship with the concept of sustainable development, as shown in Figure 1[b] (Elkington, 1994; Kemp, 2010).

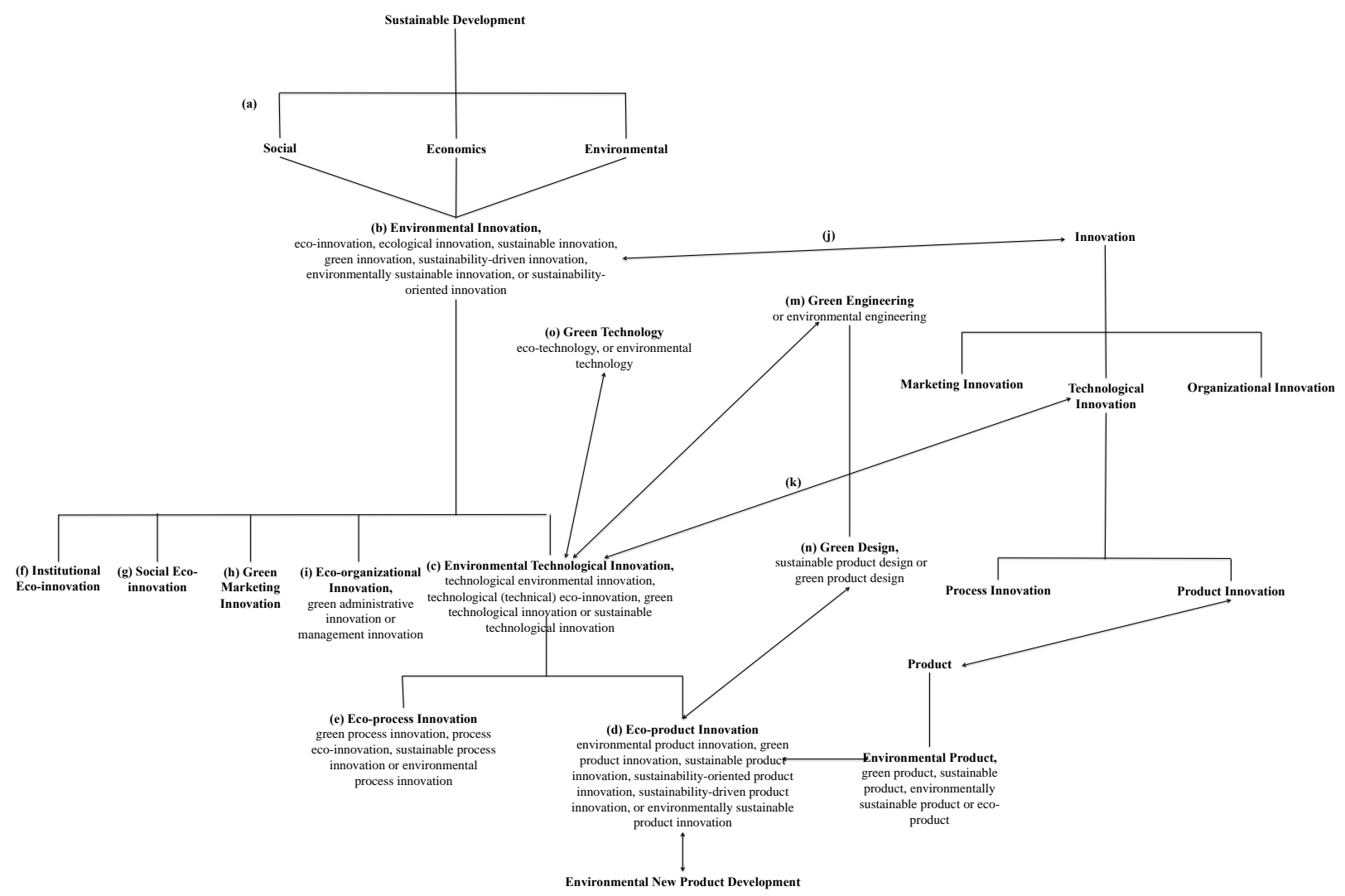

Figure 1 Concept relationship diagram of sustainable development

\subsection{Eco-innovation}

Research on eco-innovation is still in its relatively early stages with existing research spanning less than 25 years and an upsurge only after 2009. There are at least another seven terms that are being used synonymously with eco-innovation, specifically, ecological innovation, sustainable innovation, environmental innovation, green innovation, sustainability-driven innovation, environmentally sustainable innovation, and sustainability-oriented innovation (Figure 1[b]).

Since the first definition was proposed by Fussler and James in 1996, the understanding of ecoinnovation has evolved. Eco-innovation can now be summarized as the production, assimilation, or exploitation of a product, production process, service or management or business method that is novel to the organization, whether the organization develops or adopts 
it. Eco-innovation also integrates sustainability (i.e., environmental, social, and financial) considerations during the idea-generation, research, development, and commercial phases. This in turn results in a reduction in environmental risk, pollution, and other potential negative impacts of resource use (including energy use) throughout the product, process, or method life cycle compared to traditional alternatives (Kemp \& Pearson, 2007).

Eco-innovation can be categorized based on whether a technological or non-technological target is involved. ET innovation (Figure 1[c]) includes eco-product innovation (Figure 1[d]) and ecoprocess innovation (Figure 1[e]), while non-technological innovation comprises marketing, social, organizational, and institutional activities (Figure 1[f-i] (Arundel \& Kemp, 2009; Lin et al., 2014; Rashid et al., 2014).

Even though eco-innovation can be linked directly to the concept of sustainable development, there are both similarities and differences between innovation and eco-innovation (Figure 1[j]). First, the spillover effects of innovation and R\&D efforts can be found in both types of innovation. However, eco-innovation requires more external sources of knowledge and information than innovation in general. Compared to general innovation, eco-innovation creates positive impacts on the environment (Kammerer, 2009). Thus, introducing an eco-innovation policy, for example, can be seen as introducing an environmental policy. Such policies can help reduce costs at an institutional and firm level and increase eco-efficiencies (Rennings, 1998, 2000). Second, seminal studies have reported that market demand and science and technology factors are determinants of innovation (Mowery \& Rosenberg, 1979), and these factors precede eco-innovation. However, regulations can also play a more important role in eco-innovation than in other kinds of innovation (Horbach et al., 2012; de Carvalho, 2014).

\subsection{ET Innovation}

Figure 1[c] shows that ET innovation is an important subcategory of eco-innovation (Arundel \& Kemp, 2009; OECD, 2009; Rashid et al., 2014). Notwithstanding the use of the term "ET innovation," researchers may substitute other terms, including technological environmental innovation, technological (technical) eco-innovation, green technological innovation, and sustainable technological innovation. Green et al. (1994) defined ET innovation as "inventing, innovating and diffusing new sets of products and processes which somehow or other are inherently more environmentally friendly than the sets we currently make and use." There are three important components of ET innovation definitions: (1) ET innovation must be based on new technological knowledge; (2) ET innovation must be at least new to the firm; and (3) ET innovation must incorporate environmental reductions when compared to existing technologies (Rennings et al., 2006).

Conventional technological innovations and ET innovations have an indirect connection, as shown in Figure $1[\mathrm{k}]$. There are several important differences between the two concepts, however. First, ET innovation contributes to a reduction in, or avoidance of, environmental burdens (Triebswetter \& Wackerbauer, 2008). Second, ET innovations can be costlier than nonenvironmental innovations in the short term; however, in the mid- to long-term, firms can achieve their green business goals and cost savings through a reduction in the use of materials that cause environmental damage (Triguero et al., 2017). Third, major environmental impacts are caused when products are used (e.g., the $\mathrm{CO}_{2}$ emissions from cars) and during product disposal (e.g., the heavy metals in batteries) rather than only during their production. Hence, given its life-cycle approach, it is in the DNA of ET innovation to tackle this as it is not addressed in traditional product innovation (Kammerer, 2009). Finally, in ET innovation, in addition to having knowledge of customers and competitors, the need to know regulations and environmental laws is stressed (Horbach et al., 2012; de Carvalho, 2014). 


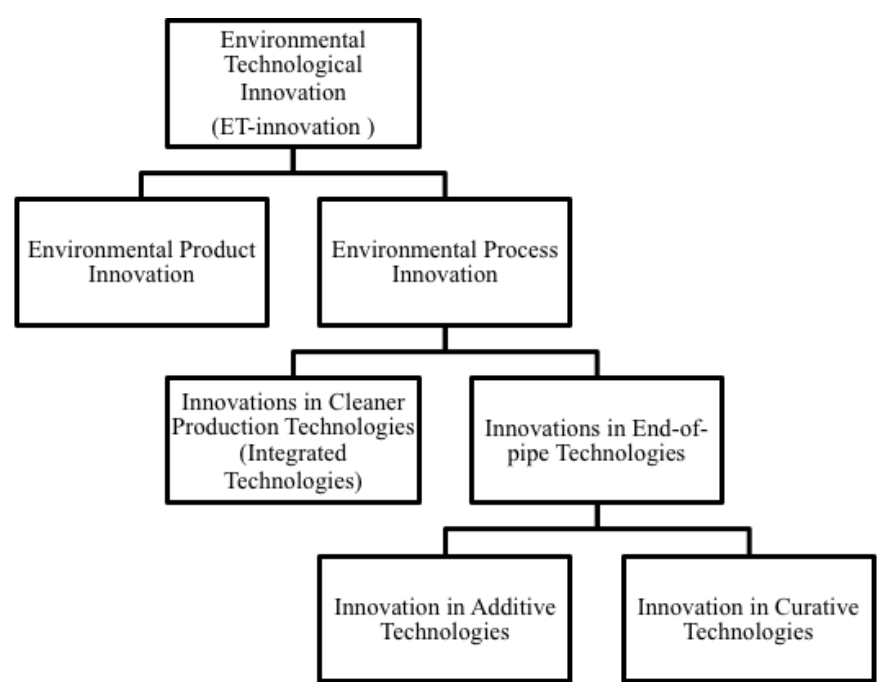

Figure 2 Typology of ET innovation

ET innovation can be separated into two specific classifications, namely, environmental process innovation and environmental product innovation, as shown in Figure 1[d \& e]. The typology of ET innovation is summarized in Figure 2. Environmental process innovations are commonly categorized into innovations in end-of-pipe technologies and innovations in integrated technologies (or cleaner production technologies). End-of-pipe technologies include preventive measures, for example, additive technologies such as pollution control and reclamations. The other component of end-of-pipe technologies involves curative technologies (e.g., the treatment of contaminated water) (Rennings et al., 2006; Guoyou et al., 2013).

ET innovation has a relationship with green engineering (Figure $1[\mathrm{~m}]$ ), which is the study of product and process design with the intention of identifying, developing, and exploiting science and technologies that can bolster productivity without damaging the environment. While green design (Figure $1[\mathrm{n}]$ ) is a segment of green engineering that aims to yield a product with a very minimum environmental impact, ET innovation has an affiliation with green technology (Figure $1[\mathrm{o}]$ ), which is the development and application of products and processes that use natural resources efficiently while simultaneously reducing and/or recycling waste, control or minimize the risks of chemical substances, and reduce pollution. As such, green engineering is the tool, green design is the practice, and green technology is the output of ET innovation.

\section{METHODOLOGY}

\subsection{Qualitative Study}

This study employed interview techniques and secondary data to fully exploit the potential of the data that was collected and analyzed. This research was exploratory in nature with the aim of analyzing, identifying, and discovering how a small sample of Malaysian firms have implemented ET innovation to achieve a competitive advantage in their respective industries. A further aim was to demonstrate how tangible ET innovation practices are in the Malaysian manufacturing industry.

The firms selected for this study were required to fulfil the following criteria:

a) The ET innovation must conform to the definition of ET innovation in Subsection 1.3.

b) The firm must have developed an eco-product or implemented an eco-process as illustrated in Figure 2. 


\subsection{Sample Selection}

Four firms were selected for this study and are identified by the codes F1, F2, F3, and F4.

F1 is a group of companies that was established in 1997. The firm produces paper-based products, which include stationery, gifts, and small aesthetic items. At the time of our study, all their products were produced using environmentally friendly equipment and their eco-products were designed by their own R\&D department. They have been recognized for their efforts in environmental practices through the Prime Minister's Hibiscus Award 2015 and the KeTTHA Greentech Industry Award 2014.

F2 is a small medium enterprise (SME) that was founded in 2009. They initially developed and produced packaging products that were $100 \%$ biodegradable. In 2010 , they start manufacturing products in a new factory complete with its own R\&D facility. At the present time, they are continuing to innovate and have an alliance with the government of Ghana that involves constructing a green facility in Ghana, known as the Green Technology Park Project, for the processing of agricultural waste into eco-packaging products.

F3 is a local subsidiary of MNC, a Fortune 500 technology company with a long history of innovation. F3 offers a variety of high-volume and high-performance electronics products. Recently, F3 extended their innovative culture to include cleaner production. One outcome of this new approach was the development of a palladium leadframe, a patented technology, as a replacement for the electroplating process. The original electroplating process produced large quantities of highly toxic wastewater and required an additional silver spot plating process, which produces cyanide (Rao, 2004). For their continued involvement in eco-process innovation and the production of eco-products, F3 has received national and international recognition, for example, the 2015 Green Award from the Melaka Green Technology Department, the Prime Minister's Hibiscus Award 2015, and Green Partner Certification from the Sony Corporation.

F4 is also an SME and was established in 2010; however, its initial R\&D was started in 2008 by its parent company. F4 is solely involved in the research, design, development, and manufacture of a plastic-to-diesel conversion plant. This initiative led to the development of curative technology equipment that can be used in waste landfill sites or installed at any manufacturing plant with plastic wastage as an additive/end-of-pipe technology. The converted diesel output can be used to operate diesel machinery and for transportation in fleet operations. In 2015, F4 signed an agreement with an international company for the exclusive distribution of their equipment in the United States and Canada.

\subsection{Data Collection and Analysis}

An historical analysis of the selected firms was conducted to understand the conceptualization, development, and introduction of their ET innovation. Since the development of environmental innovation is a time-dependent process, looking at the development of innovation from a historical perspective can lead to a better understanding of the process.

Interviews were conducted with key managers in the firms who were directly involved with the ET innovation projects from inception to implementation. The seven stages of interview investigation (i.e., thematizing, designing, interviewing, transcribing, analyzing, verifying, and reporting) were followed and helped make the interviews more effective (Butler, 2004). The interview process with each participant was semi-structured with modified Sloan Study questions (Yusuf et al., 2018). 


\section{DISCUSSION}

The selected firms implemented a combination of different types of ET innovation at the same time (Table 1). Involvement in ET innovation has increased these firms' competitive advantage. With their improved capabilities, they have also increased their ability to venture into new markets and explore new technologies (Porter, 1990; Triguero et al., 2017). This result demonstrates that Malaysian firms have the capability to be involved in many areas of ET innovation. This is significant because the Malaysian government has shifted its focus from an agricultural to a knowledge-based to an innovation-centered economy where innovation is the driver of economic growth (Halim et al., 2016). In addition, the GDP for green businesses in Malaysia is forecasted to be about RM60 billion by 2030, and green technology investments are estimated to be RM86 billion by the same year (Spykerman, 2015). Conversely, if these type of activities were to be overlooked, according to the Asian Development Bank, Malaysia may risk reducing its GDP by between 7\% and $8 \%$ by 2030 (Amran et al., 2013).

Table 1 ET innovation type by Malaysian firm

\begin{tabular}{cl}
\hline Firms & \multicolumn{1}{c}{ ET innovation type } \\
\hline F1 & Eco-product innovation and integrated eco-process innovation \\
\hline F2 & $\begin{array}{l}\text { Eco-product innovation, integrated eco-process innovation (cleaner production), } \\
\text { innovation in curative technologies }\end{array}$ \\
\hline F3 & Eco-product innovation, integrated eco-process innovation (cleaner production) \\
\hline F4 & Innovation in end-of-pipe technologies (additive and curative) \\
\hline
\end{tabular}

Malaysian firms that export their products to international markets have been forced to accept the new norm in which global companies are pursuing sustainable development (Hojnik \& Ruzzier, 2016). The studied firms followed this trend and therefore had the confidence to venture into international business trading. This increased competition will pressure other local firms to implement ET innovation strategies and improve their technologies, services, quality, and reliability (Tseng et al., 2013). Firms that have improved their products and processes for the international market can have an indirect effect on the domestic market because their ecoproducts and clean technologies will also be marketed in Malaysia. This in turn will exert pressure on upstream suppliers and their domestic competitors to improve their environmental practices. This view is also referred to in the literature as the green multiplier effect (Eltayeb et al., 2010; Ye et al., 2013).

Unfortunately, except for F3, the firms in our study gave the impression that they lacked a customer focus. Lo et al., (2016) determined empirically that investment in market orientation resources is costly for Malaysian firms. Manufacturing new and innovative eco-products needs significant capital investment in $\mathrm{R} \& \mathrm{D}$, technology, and equipment, while eco-process innovation requires expenditure on manpower advancement with respect to technological know-how and equipment expertise (Tseng et al., 2013; Meutia \& Ismail, 2015; Abdullah et al., 2016). At least three of the firms in our study received green technology financing from GreenTech Malaysia. As the Malaysian industry is a transitional knowledge-based industry, ET innovation investments need to be directed toward $R \& D$, a key resource for firms that pushes management to opt for internal resources and technological know-how instead of market orientation and a customer focus (Zhou \& Li, 2010; Magnani \& Tubb, 2012).

\section{CONCLUSION}

The possible contribution of ET innovation toward achieving the global Sustainable Development Goals has been explained in this paper through the concept relationship diagram. 
This diagram can be used as a guideline for research and activities with sustainability objectives.

The information obtained from the firms in our study indicated some of the trends in the manufacturing industry in Malaysia. However, further empirical analysis and a different scope would be valuable in understanding what the Malaysian industry can contribute to sustainable development initiatives through the implementation of ET innovation.

\section{ACKNOWLEDGEMENT}

The authors would like to thank the management of the firms that participated in this research for their valuable cooperation as well as the anonymous reviewers for their comments. Some similarities may be found with the authors' article in a different journal. These are not intentional because the focus is different.

\section{REFERENCES}

Abdullah, M., Zailani, S., Iranmanesh, M., Jayaraman, K., 2016. Barriers to Green Innovation Initiatives among Manufacturers: The Malaysian Case. Review of Managerial Science, Volume 10(4), pp. 683-709

Amran, A., Zainuddin, Z., Zailani, S.H.M., 2013. Carbon Trading in Malaysia: Review of Policies and Practices. Sustainable Development, Volume 21(3), pp. 183-192

Arundel, A., Kemp, R., 2009. Measuring Eco-innovation. Maastricht: UNU-Merit

BSI/ISO, 2015. BS EN ISO 9000: 2015 Quality Management Systems - Fundamentals and Vocabulary. London, United Kingdom: BSI Standards Publication

Butler, T., 2004. Leveraging Sustainability: How Companies Enhance Their Eco-innovation Success. Troy, New York: Rensselaer Polytechnic Institute

de Carvalho, F.P., 2014. Portraying the Eco-innovative Landscape in Brazil: Determinants, Processes, and Results. In: Eco-innovation and the Development of Business Models. Azevedo, S., Brandenburg, M., Carvalho, H., Cruz-Machado, V., (eds.). Cham: Springer International Publishing, Volume 2, pp. 117-136

Dalal-Clayton, B., Bass, S., 2000. National Strategies for Sustainable Development: The Challenge Ahead, Environmental Planning Issues. London: International Institute for Environment and Development

Elkington, J., 1994. Towards the Sustainable Corporation: Win-win-win Business Strategies for Sustainable Development. California Management Review, Volume 36(2), pp. 90-100

Eltayeb, T.K., Zailani, S., Jayaraman, K., 2010. The Examination on the Drivers for Green Purchasing Adoption Among EMS 14001 Certified Companies in Malaysia. Journal of Manufacturing Technology Management, Volume 21(2), pp. 206-225

Fussler, C., James, P., 1996. Driving Eco-innovation - A Breakthrough Discipline for Innovation and Sustainability. London: Pitman Publishing

Giddings, B., Hopwood, B., O’Brien, G., 2002. Environment, Economy and Society: Fitting Them Together into Sustainable Development. Sustainable Development, Volume 10(4), pp. $187-196$

Gladwin, T.N., Kennelly, J.J., Krause, T.S., 1995. Shifting Paradigms for Sustainable Development: Implications for Management Theory and Research. Academy of Management Review, Volume 20(4), pp. 874-907

Green, K., McMeekin, A., Irwin, A., 1994. Technological Trajectories and R\&D for Environmental Innovation in UK Firms. Futures, Volume 26(10), pp. 1047-1059

Guoyou, Q., Saixing, Z., Chiming, T., Haitao, Y., Hailiang, Z., 2013. Stakeholders' Influences on Corporate Green Innovation Strategy: A Case Study of Manufacturing Firms in China. Corporate Social Responsibility and Environmental Management, Volume 20(1), pp. 1-14 
Halim, H.A., Ahmad, N.H., Ramayah, T., Taghizadeh, S.K., 2016. Capturing the 'Pioneering Minds' via Human Capital: The Impact on Innovative Performance of Malaysian SMEs. Asian Academy of Management Journal, Volume 21(1), pp. 105-126

Hojnik, J., Ruzzier, M., 2016. The Driving Forces of Process Eco-innovation and Its Impact on Performance: Insights from Slovenia. Journal of Cleaner Production. Volume 133, pp. 812-825

Horbach, J., Rammer, C., Rennings, K., 2012. Determinants of Eco-innovations by Type of Environmental Impact-The Role of Regulatory Push/Pull, Technology Push and Market Pull. Ecological Economics. Volume 78(11), pp. 112-122

Kammerer, D., 2009. The Effects of Customer Benefit and Regulation on Environmental Product Innovation: Empirical Evidence from Appliance Manufacturers in Germany. Ecological Economics. Volume 68(8-9), pp. 2285-2295

Kemp, R., 2010. Eco-innovation: Definition, Measurement and Open Research Issues. Economia Politica, Volume 27(3), pp. 397-420

Kemp, R., Pearson, P., 2007. Deliverable 15. Final Report of the MEI Project about Measuring Eco Innovation. Maastricht, Netherlands: UM-MERIT

Kruja, A.D., 2013. Sustainable Economic Development, a Necessity of the $21^{\text {st }}$ Century. Mediterranean Journal of Social Sciences, Volume 4(10), pp. 93-98

Lin, R.J., Chen, R.H., Huang, F.H., 2014. Green Innovation in the Automobile Industry. Industrial Management \& Data Systems. Volume 114(6), pp. 886-903

Lo, M.C., Wang, Y.C., Wah, C.R.J., Ramayah, T., 2016. The Critical Success Factors for Organizational Performance of SMEs in Malaysia: A Partial Least Squares Approach. Review of Business Management, Volume 18(61), pp. 370-391

Magnani, E., Tubb, A., 2012. Green R\&D, Technology Spillovers, and Market Uncertainty: An Empirical Investigation. Land Economics, Volume 88(4), pp. 685-709

Meadows, D.H., Meadows, D.L., Randers, J.J., Behrens, W.W., Rome, C.O., 1972. The Limits To Growth, A Report for the Club of Rome's Project on the Predicament of Mankind. New York: Universe Books

Meutia, Ismail, T., 2015. The Influence of Competitive Pressure on Innovative Creativity. Academy of Strategic Management Journal, Volume 14(2), pp. 117-127

Mowery, D., Rosenberg, N., 1979. The Influence of Market Demand Upon Innovation: A Critical Review of Some Recent Empirical Studies. Research Policy, Volume 8(2), pp. $102-153$

OECD, 2009. Sustainable Manufacturing and Eco-innovation: Framework, Practices and Measurement Synthesis Report. Paris: OECD Committee on Industry, Innovation and Entrepreneurship (CIIE)

Pansera, M., 2012. The Origins and Purpose of Eco-innovation. Global Environment. A Journal of History and Natural and Social Sciences, Volume 7/8, pp. 128-155

Porter, M.E., 1990. The Competitive Advantage of Nations. Harvard Business Review, pp. $73-$ 91

Rao, P., 2004. Greening Production: A South-East Asian Experience. International Journal of Operations \& Production Management, Volume 24(3), pp. 289-320

Rashid, L., Yahya, S., Shamee, S.A., Jabar, J., Sedek, M., Halim, S., 2014. Eco Product Innovation in Search of Meaning: Incremental and Radical Practice for Sustainability Development. Asian Social Science. Volume 10(13), pp. 78-88

Rennings, K., 1998. Towards a Theory and Policy of Eco-Innovation-Neoclassical and (Co-) Evolutionary Perspectives, ZEW Discussion Paper. Mannheim, Germany: ZEW - Zentrum für Europäische Wirtschaftsforschung/Center for European Economic Research

Rennings, K., 2000. Redefining Innovation - Eco-innovation Research and the Contribution from Ecological Economics. Ecological Economics, Volume 32(2), pp. 319-332 
Rennings, K., Ziegler, A., Ankele, K., Hoffmann, E., 2006. The Influence of Different Characteristics of the EU Environmental Management and Auditing Scheme on Technical Environmental Innovations and Economic Performance. Ecological Economics, Volume 57(1), pp. 45-59

Seghezzo, L., 2009. The Five Dimensions of Sustainability. Environmental Politics, Volume 18(4), pp. 539-556

Spykerman, N., 2015. PM Banking on Green Biz. Available Online at http://www.thestar.com.my/News/Nation/2015/09/12/PM-banking-on-green-biz-Ecosector-can-help-boost-GDP/

Triebswetter, U., Wackerbauer, J., 2008. Integrated Environmental Product Innovation in the Region of Munich and Its Impact on Company Competitiveness. Journal of Cleaner Production, Volume 16(14), pp. 1484-1493

Triguero, Á., Cuerva, M.C., Álvarez-Aledo, C., 2017. Environmental Innovation and Employment: Drivers and Synergies. Sustainability, Volume 9(11), p. 2057

Tseng, M.L., Wang, R., Chiu, A.S.F., Geng, Y., Lin, Y.H., 2013. Improving Performance of Green Innovation Practices Under Uncertainty. Journal of Cleaner Production. Volume 40, pp. $71-82$

Turcu, C., 2013. Re-thinking Sustainability Indicators: Local Perspectives of Urban Sustainability. Journal of Environmental Planning and Management, Volume 56(5), pp. 695-719

World Commission on Environment and Development (WCED), 1987. Report of the World Commission on Environment and Development: Our Common Future. Geneva: WCED, United Nations

Ye, F., Zhao, X., Prahinski, C., Li, Y., 2013. The Impact of Institutional Pressures, Top Managers' Posture and Reverse Logistics on Performance-Evidence from China. International Journal of Production Economics. Volume 143(1), pp. 132-143

Yusuf, M.F., Ashari, H., Razalli, M.R., 2018. A Study on the Environmental Technological Innovation Strategy of a Malaysian Firm. International Journal of Engineering \& Technology, Volume 7, pp. 261-268

Zhou, K.Z., Li, C.B., 2010. How Strategic Orientations Influence the Building of Dynamic Capability in Emerging Economies. Journal of Business Research. Volume 63(3), pp. 224231 